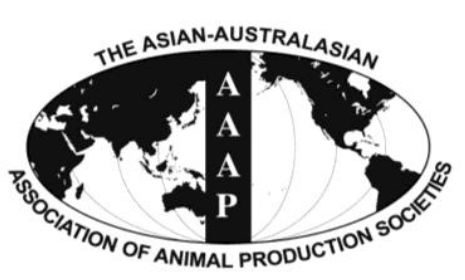

Open Access

Asian Australas. J. Anim. Sci.

Vol. 27, No. 8 : 1131-1140 August 2014

http://dx.doi.org/10.5713/ajas.2013.13737

\author{
www.ajas.info
}

pISSN 1011-2367 elSSN 1976-5517

\title{
Effects of Bacillus subtilis KN-42 on Growth Performance, Diarrhea and Faecal Bacterial Flora of Weaned Piglets
}

\author{
Yuanliang $\mathrm{Hu}^{1,2}$, Yaohao Dun ${ }^{1}$, Shenao $\mathrm{Li}^{1}$, Shumiao Zhao ${ }^{1}$, Nan Peng ${ }^{1}$, and Yunxiang Liang ${ }^{1}$ ** \\ ${ }^{1}$ State Key Laboratory of Agricultural Microbiology, College of Life Science and Technology, \\ Huazhong Agricultural University, Wuhan 430070, China
}

\begin{abstract}
This research focused on the effects of different doses of Bacillus subtilis $\mathrm{KN}-42$ on the growth performance, diarrhea incidence, faecal bacterial flora, and the relative number of Lactobacillus and Escherichia coli in faeces of weaned piglets to determine whether the strain can serve as a candidate antimicrobial growth promoter. A total of 360 piglets (initial body weight $7.14 \pm 0.63 \mathrm{~kg}$ ) weaned at $26 \pm 2$ days of age were randomly allotted to 5 treatment groups ( 4 pens per treatment with 18 pigs per pen) for a 28 -day trial. Dietary treatments were basal diet without any antimicrobial (negative control; NC), basal diet supplemented with $120 \mathrm{mg} / \mathrm{kg}$ feed of neomycin sulfate (positive control; PC) and basal diet supplemented with $2 \times 10^{9}$ (L), $4 \times 10^{9}$ (M) and $20 \times 10^{9}$ (H) CFU/kg feed of $B$. subtilis $\mathrm{KN}-42$. During the overall period, average daily gain and feed efficiency of piglets were higher in groups PC, M, and $\mathrm{H}$ than those in group NC $(\mathrm{p}<0.05)$, and all probiotics and antibiotics groups had a lower diarrhea index than group NC $(\mathrm{p}<0.05)$. The $16 \mathrm{~S}$ rDNA gene-based methods were used to analyze faecal bacterial flora on day 28 of experiment. The result of denaturing gradient gel electrophoresis analysis showed that supplementation of $B$. subtilis $\mathrm{KN}-42$ to the diet changed the bacterial communities, with a higher bacterial diversity and band number in group $\mathrm{M}$ than in the other four groups. Real-time polymerase chain reaction analysis showed that the relative number of Lactobacillus were higher in groups $\mathrm{PC}$ and $\mathrm{H}$ than in group $\mathrm{NC}(\mathrm{p}<0.05)$, and the supplemented $B$. subtilis $\mathrm{KN}$ 42 to the diet also reduced the relative number of $E$. coli $(\mathrm{p}<0.05)$. These results suggest that dietary addition of $B$. subtilis $\mathrm{KN}-42$ can improve the growth performance and gastrointestinal health of piglets. (Key Words: Bacillus subtilis, Bacterial Community, Diarrhea, Growth Performance, Lactobacillus, Weaned Piglets)
\end{abstract}

\section{INTRODUCTION}

The health state of weaned piglets has an enormous impact on their subsequent performance in adaptation to nutritional, psychological and environmental stressors. These stressors may result in low feed intake, low weight gain and poor health, and thus growth-promoting antibiotics are usually used to improve animal growth and health. However, recent studies have found the horizontal transfer of antibiotic resistance genes between bacteria from farm animals, human food and humans (Smillie et al., 2011; Hu et al., 2013). Concerns about transference of antibiotic

\footnotetext{
* Corresponding Author: Yunxiang Liang. Tel: +86-27-87281040, Fax: +86-27-8728-0670, E-mail: fa-lyx@163.com

${ }^{2}$ College of Life Sciences, Hubei Normal University, Huangshi, Hubei 435002, China.

Submitted Nov. 21, 2013; Revised Jan. 24, 2014; Accepted Mar. 25, 2014
}

resistance genes from animals to humans led to withdraw approval for antibiotics as growth promoters in the European Union in 2006. Currently, more countries are making a greater effort to ban on the use of antibiotics as animal growth promoters.

Probiotics are defined as live microorganisms that produce a health benefit when administered in adequate amounts to animals, including humans (Sindhu and Khetarpaul, 2003). They are potential alternatives to growth promoting antibiotics which can affect the health of pigs. Among several bacterial species used as probiotics, Bacillus subtilis was once thought to be a strict aerobe, but now known as a facultative anaerobe, which is preferred due to the high resistance of its spores to harsh environment and long-term storage at ambient temperature (Nakano and Zuber, 1998; Hong et al., 2005). The intestinal microflora has been suggested to play an important role in the growth 
of weaned piglets, and $B$. subtilis is an intestinal microorganism that may grow in the gut and consume the oxygen to maintain an anaerobic environment for the prevention or therapy of gastrointestinal disorders.

Many previous studies have reported that dietary supplementation of $B$. subtilis could have some beneficial effects on digestibility and intestinal microbes, thus improving the growth performance of animals (Aliakbarpour et al., 2012; Kim et al., 2012; Sen et al., 2012; Zhang et al., 2012; Tsukahara et al., 2013). Furthermore, B. subtilis LS 1-2 is reported to have wideranging effects on the intestinal morphology, microbial population and immune status of weanling pigs (Lee et al., 2014). However, it was also found that animals supplemented with probiotics did not always result in better growth performance (Lee et al., 2010). The effect of probiotics depends on the combination of selected bacterial genera, their doses, and feed composition (Vondruskova et al., 2010).

The goal of this study was to investigate the effect of $B$. subtilis $\mathrm{KN}-42$ on the growth performance, diarrhea incidence, faecal Lactobacillus, Escherichia coli and bacterial diversity of weaned piglets. Denaturing gradient gel electrophoresis (DGGE) was used to characterize the bacterial diversity of faeces, and real-time polymerase chain reaction (PCR) was used to measure the copy number of Lactobacillus and E. coli.

\section{MATERIALS AND METHODS}

\section{Probiotics}

The B. subtilis KN-42 (CCTCC No: M 208249) was certified as feed additives by the Ministry of Agriculture of People's Republic of China (No: [2009] 2563). The product was composed of spray-dried spore-forming $B$. subtilis containing at least $20 \times 10^{9} \mathrm{CFU} / \mathrm{g}$ and was donated by a commercial company (Kenuo Biotechnology CO., LTD., Wuhan, China).

\section{Animals and experimental design}

Piglets (Duroc $\times[$ Landrace $\times$ Yorkshire], 82 litters) were obtained from a farm with 3,000 sows (Hainan AgriFarming Animal Husbandry Group, Haikou, China). At weaning, a total of 360 healthy piglets (initial body weight $7.14 \pm 0.63 \mathrm{~kg} ; 26 \pm 2$ days of age) were selected for a 28 -day trial. The piglets were randomly divided into 20 pens, balanced for sex, body weight and litter origin, with 18 piglets in each pen (male: female, 1:1). According to a completely randomized design, the piglets were allotted to 5 treatments with 4 replicates. Dietary treatments were basal diet without any antimicrobial (negative control; NC), basal diet supplemented with $120 \mathrm{mg} / \mathrm{kg}$ feed of neomycin sulfate (positive control; PC) and basal diet supplemented with
$2 \times 10^{9}(\mathrm{~L}), 4 \times 10^{9}(\mathrm{M})$ and $20 \times 10^{9}(\mathrm{H}) \mathrm{CFU} / \mathrm{kg}$ feed of $B$. subtilis $\mathrm{KN}-42$.

Experimental diets were fed in two phases (phase I: $\mathrm{d} 1$ to 14 and phase II: $\mathrm{d} 15$ to 28 post weaning; Table 1), and all diets met or exceeded nutrients requirement recommended by NRC (1998). During the experiment, all piglets were housed in a temperature-controlled nursery room $\left(25 \pm 2^{\circ} \mathrm{C}\right)$. Feed and water were available ad libitum. All piglets were vaccinated against pseudorabies, foot-andmouth disease, circovirus, blue-ear disease, asthma and hog cholera before the experiment.

Feed intake and body weight were measured at the end of each phase to determine average daily gain (ADG), average daily feed intake (ADFI), and feed efficiency (G/F). During the experiment, all piglets were checked daily, and those that had loose faeces (pasty, thick, fluid or watery) were recorded as diarrheal pigs (Giang et al., 2012). The incidence of diarrhea (\%) was calculated by the total

Table 1. Ingredient and chemical composition of basal diets

\begin{tabular}{lcc}
\hline Item & $\begin{array}{c}\text { Phase I } \\
\text { (d 1 to 14) }\end{array}$ & $\begin{array}{c}\text { Phase II } \\
\text { (d 15 to 28) }\end{array}$ \\
\hline Ingredient (\%) & & \\
Corn, yellow & 47.59 & 60.13 \\
Soybean meal (43\% CP) & 10.00 & 16.00 \\
Spray dried plasma protein & 3.50 & - \\
Fish meal & 5.00 & 5.00 \\
Dried whey & 26.50 & 14.00 \\
Dicalcium phosphate & 1.05 & 1.40 \\
Limestone & 0.15 & 0.15 \\
L-lysine-HCL (98\%) & 0.39 & 0.43 \\
DL-methionine (99\%) & 0.17 & 0.14 \\
Sugar & 3.00 & - \\
Salt & 0.20 & 0.30 \\
Corn starch & 1.40 & 1.40 \\
Vitamin/mineral premix ${ }^{1}$ & 1.05 & 1.05 \\
Chemical composition & & \\
ME (kcal/kg) & 3645 & 3458 \\
CP (\%) & 20.5 & 19.0 \\
Lys (\%) & 1.60 & 1.48 \\
Met (\%) & 0.91 & 0.80 \\
Ca (\%) & 0.69 & 0.59 \\
P (\%) & 0.50 & 0.45 \\
\hline CP, &
\end{tabular}

$\mathrm{CP}$, crude protein; ME, metabolizable energy.

Dietary treatments: NC (negative control, basal diet without any antimicrobial); PC (positive control, diet supplemented with $120 \mathrm{mg} / \mathrm{kg}$ of neomycin sulfate); L, M, H (diets supplemented with probiotics $2 \times 10^{9}$, $4 \times 10^{9}$ and $20 \times 10^{9} \mathrm{CFU} / \mathrm{kg}$ feed, respectively); Antibiotics and probiotic products were added to the diets at the expense of corn starch.

${ }^{1}$ Provided the following per $\mathrm{kg}$ of diet: 12,800 IU vitamin A, 4,000 IU vitamin $D_{3}, 80 \mathrm{mg}$ vitamin $E, 4 \mathrm{mg}$ vitamin $B_{1}, 10 \mathrm{mg}$ vitamin $B_{2}, 6 \mathrm{mg}$ vitamin $\mathrm{B}_{6}, 46 \mu \mathrm{g}$ vitamin $\mathrm{B}_{12}, 4 \mathrm{mg}$ vitamin $\mathrm{K}_{3}, 20 \mathrm{mg}$ pantothenic acid, $40 \mathrm{mg}$ nicotinic acid, $0.36 \mathrm{mg}$ biotin, $2 \mathrm{mg}$ folic acid, $500 \mathrm{mg}$ choline chloride; $80 \mathrm{mg} \mathrm{Mn}\left(\mathrm{MnSO}_{4}\right), 200 \mathrm{mg} \mathrm{Fe}\left(\mathrm{FeSO}_{4}\right), 40 \mathrm{mg} \mathrm{Cu}\left(\mathrm{CuSO}_{4}\right)$, $120 \mathrm{mg} \mathrm{Zn}\left(\mathrm{ZnSO}_{4}\right), 0.4 \mathrm{mg} \mathrm{I}\left(\mathrm{Ca}\left(\mathrm{IO}_{3}\right)_{2}\right), 0.25 \mathrm{mg} \mathrm{Co}\left(\mathrm{CoSO}_{4}\right)$, and 0.4 $\mathrm{mg} \mathrm{Se}\left(\mathrm{Na}_{2} \mathrm{SeO}_{3}\right)$. 
number of diarrheal piglets over a period divided by the number of piglets and days in that period multiplied by 100 . On day 28 of the experiment, faecal samples (5 piglets for each treatment, at least 1 piglet per pen) were collected by rectal massage and stored at $-80^{\circ} \mathrm{C}$.

DNA extraction and polymerase chain reactiondenaturing gradient gel electrophoresis

The DNA from faecal samples was extracted with the QIAamp DNA Stool Mini Kit (Qiagen, Duesseldorf, Germany) according to the manufacturer's instructions, at $95^{\circ} \mathrm{C}$ for the initial lysis step (Li et al., 2003). DNA was eluted from the matrix using $100 \mu \mathrm{L}$ elution buffer, and stored at $-20^{\circ} \mathrm{C}$ before use. DNA concentration and quantity were tested on a Nanodrop ND-100 spectrophotometer (Thermo, Wilmington, DE, USA).

The $50 \mu \mathrm{L}$ PCR reaction mixture contained $5 \mu \mathrm{L}$ of $10 \times$ PCR buffer (Takara, Dalian, China), $2 \mu \mathrm{L}$ of dNTPs $(2.5$ $\mathrm{mM}$ of each, Takara), $1 \mu \mathrm{L}$ of each primer $(10 \mu \mathrm{M}), 2.5 \mathrm{U}$ of Taq polymerase (Takara) and $50 \mathrm{ng}$ template DNA. The primers were 968F-GC and 1401R (Table 2; Invitrogen, Shanghai, China) targeted to the V6 V8 regions of $16 \mathrm{~S}$ rDNA. The DNA was amplified under following conditions: 1 cycle for $7 \mathrm{~min}$ at $94^{\circ} \mathrm{C}, 35$ cycles of $\left(94^{\circ} \mathrm{C}\right.$ for $30 \mathrm{~s}, 56^{\circ} \mathrm{C}$ for $20 \mathrm{~s}, 68^{\circ} \mathrm{C}$ for $30 \mathrm{~s}$ ) and a final elongation of $7 \mathrm{~min}$ at $68^{\circ} \mathrm{C}$ in the T100 Thermal Cycler (Bio-Rad, Hercules, CA, USA). The PCR products from the same group (5 piglets) were mixed together as one sample. Before running on DGGE gels, the PCR products were cleaned using a PCR Purification Kit (Omega, Norcross, GA, USA).

The DGGE analysis was performed using the DCode Universal Mutation Detection System (Bio-Rad) as described by Walter et al. (2000) with the following modifications. Using a denaturant gradient range from $42 \%$ to $58 \%, 10 \mu \mathrm{L}$ of purified DNA samples $(32 \mathrm{ng} / \mu \mathrm{L})$ was subjected to electrophoresis at $10 \mathrm{~V}$ for $10 \mathrm{~min}$ at $60^{\circ} \mathrm{C}$ and subsequently at $85 \mathrm{~V}$ for $16 \mathrm{~h}$ in $0.5 \times \mathrm{TAE}$ buffer at $60^{\circ} \mathrm{C}$. The DNA bands in gels were visualized by silver staining (van Orsouw et al., 1997).

\section{Denaturing gradient gel electrophoresis band sequencing and analysis}

Excision and purification of DNA fragments from DGGE gels were performed as described by Ben Omar and Ampe (2000). The purified DNA (5 $\mu \mathrm{L})$ was amplified using the same primers and reaction conditions as previously described except that the GC clamp was excluded from the forward primer (Table 2). The PCR products were cleaned using a PCR Purification Kit (Omega) and sequenced by Invitrogen (Shanghai, China) using an ABI Prism 377 sequencer (ABI, Foster, CA, USA). The closest relatives were identified by comparing newly determined sequences with those available in the V6-V8 regions of the 16S rDNA gene sequences in the GenBank DNA database (www.ncbi.nih.gov). The identities of the relatives were determined on the basis of the highest score.

Quantity One (version 4.6.2; Bio-Rad) was used for band analysis. The number of bands detected in a DGGE lane was used as a measure of the number of species present (species richness, S). For each sample, diversity indices were calculated based on the gauss trace quality, which was determined using background subtraction as an estimate of the relative population size of each species. Shannon-wiener diversity index $\left(\mathrm{H}^{\prime}\right)$, species evenness $(\mathrm{J})$, Berger-Parker index (d) and Simpson's index (1/D) were calculated using the software BIO-DAP (Fundy National Park, Canada).

\section{Quantitative real-time polymerase chain reaction analysis \\ Quantitative real-time PCR (qPCR) was performed} using previously described primer sets and annealing temperatures (Table 2). Counts for total bacteria, Lactobacillus and E. coli were obtained. Amplification was performed in an Applied Biosystems ViiA 7 Real-time PCR System (ABI) using an iTaq Universal SYBR Green Supermix (Bio-Rad) as follows: 1 cycle at $95^{\circ} \mathrm{C}$ for $10 \mathrm{~min}$, and 40 cycles of $\left(95^{\circ} \mathrm{C}\right.$ for $15 \mathrm{~s}, 50^{\circ} \mathrm{C}$ to $60^{\circ} \mathrm{C}$ [Table 2] for $20 \mathrm{~s}$ and $72^{\circ} \mathrm{C}$ for $\left.30 \mathrm{~s}\right)$. The data were collected at the extension step $\left(72^{\circ} \mathrm{C}\right.$ for $\left.30 \mathrm{~s}\right)$. Standard curves were generated using serial dilutions $\left(10^{2}\right.$ to $\left.10^{7}\right)$ of purified

Table 2. Primers used for denaturing gradient gel electrophoresis (DGGE) and real-time PCR

\begin{tabular}{|c|c|c|c|c|}
\hline Target group & Prime sequence $\left(5^{\prime} \rightarrow 3^{\prime}\right)$ & $\begin{array}{l}\text { Amplicon size } \\
\text { (bp) }\end{array}$ & $\begin{array}{l}\text { Annealing } \\
\text { temp }\left({ }^{\circ} \mathrm{C}\right)\end{array}$ & Reference \\
\hline Total bacteria of DGGE & $\begin{array}{l}\text { AACGCGAAGAACCTTAC }\left(968 \mathrm{~F}-G^{1}\right) \\
\text { CGGTGTGTACAAGACCC }(1401 \mathrm{R})\end{array}$ & 435 & 56 & Ricca et al. (2010) \\
\hline Total bacteria & $\begin{array}{l}\text { CGGYCCAGACTCCTACGGG } \\
\text { TTACCGCGGCTGCTGGCAC }\end{array}$ & 200 & 60 & Lee et al. (1996) \\
\hline Lactobacillus & $\begin{array}{l}\text { CGATGAGTGCTAGGTGTTGGA } \\
\text { CAAGATGTCAAGACCTGGTAAG }\end{array}$ & 186 & 60 & Fu et al. (2006) \\
\hline Escherichia coli & $\begin{array}{l}\text { CAATGGTGATGTCAGCGTT } \\
\text { ACACTCTGTCCGGCTTTTG }\end{array}$ & 163 & 58 & Srinivasan et al. (2011) \\
\hline
\end{tabular}

PCR, polymerase chain reaction

${ }^{1}$ GC clamp (5'-CGCCCGGGGCGCGCCCCGGGCGGCCCGGGGGCACCGGGGG-3'). 
Table 3. Average daily gain (ADG), average daily feed intake (ADFI) and feed efficiency (G/F) of weaned piglets ${ }^{1}$ fed diet supplemented with antibiotics or B. subtilis

\begin{tabular}{|c|c|c|c|c|c|c|c|}
\hline Item & $\mathrm{NC}$ & $\mathrm{PC}$ & $\mathrm{L}^{2}$ & $\mathrm{M}^{2}$ & $\overline{\mathrm{H}^{2}}$ & SEM & $p$ value \\
\hline Initial weight (kg) & 7.22 & 7.08 & 7.18 & 7.07 & 7.14 & 0.15 & 0.998 \\
\hline \multicolumn{8}{|l|}{ Phase I (d 1 to 14$)$} \\
\hline ADG (g/d) & 245 & 249 & 257 & 259 & 275 & 3.73 & 0.074 \\
\hline ADFI (g/d) & 378 & 356 & 362 & 368 & 365 & 3.50 & 0.425 \\
\hline $\mathrm{G} / \mathrm{F}(\mathrm{g} / \mathrm{kg})$ & $648^{\mathrm{c}}$ & $696^{\mathrm{bc}}$ & $710^{\mathrm{ab}}$ & $704^{\mathrm{ab}}$ & $754^{\mathrm{a}}$ & 9.17 & $<0.001$ \\
\hline \multicolumn{8}{|l|}{ Phase II (d 15 to 28 ) } \\
\hline $\mathrm{ADG}(\mathrm{g} / \mathrm{d})$ & $353^{\mathrm{b}}$ & $411^{\mathrm{a}}$ & $384^{\mathrm{ab}}$ & $404^{\mathrm{a}}$ & $389^{\mathrm{a}}$ & 5.51 & 0.001 \\
\hline ADFI (g/d) & 676 & 720 & 728 & 721 & 717 & 8.66 & 0.359 \\
\hline $\mathrm{G} / \mathrm{F}(\mathrm{g} / \mathrm{kg})$ & $522^{\mathrm{c}}$ & $571^{\mathrm{a}}$ & $528^{\mathrm{bc}}$ & $560^{\mathrm{ab}}$ & $543^{\mathrm{abc}}$ & 5.36 & 0.004 \\
\hline \multicolumn{8}{|l|}{ Overall (d 1 to 28$)$} \\
\hline $\mathrm{ADG}(\mathrm{g} / \mathrm{d})$ & $299^{\mathrm{b}}$ & $330^{\mathrm{a}}$ & $321^{\mathrm{ab}}$ & $331^{\mathrm{a}}$ & $332^{\mathrm{a}}$ & 3.72 & 0.006 \\
\hline ADFI (g/d) & 527 & 539 & 545 & 545 & 541 & 5.14 & 0.837 \\
\hline $\mathrm{G} / \mathrm{F}(\mathrm{g} / \mathrm{kg})$ & $567^{\mathrm{b}}$ & $612^{\mathrm{a}}$ & $588^{\mathrm{ab}}$ & $609^{a}$ & $614^{\mathrm{a}}$ & 4.97 & 0.001 \\
\hline
\end{tabular}

NC, negative control, basal diet; PC, positive control, diet supplemented with antibiotics; SEM, standard error of the mean.

${ }^{1} 20$ pens of piglets (18 piglets per pen) with pen as the experimental unit, and each mean based on 4 replicates.

${ }^{2} \mathrm{~L}, \mathrm{M}, \mathrm{H}=$ diets supplemented with probiotics $2 \times 10^{9}, 4 \times 10^{9}$, and $20 \times 10^{9} \mathrm{CFU} / \mathrm{kg}$ feed, respectively.

${ }^{\mathrm{a}, \mathrm{b}, \mathrm{c}}$ Mean values in the same row with different superscripts differ significantly $(\mathrm{p}<0.05)$.

genomic DNA obtained by standard PCR with corresponding primers. After amplification, the melting curves were checked to confirm the amplification results. The total counts were expressed in $\log _{10}$ gene copy number $/ \mu \mathrm{L}$, whereas the values for the other bacterial groups were expressed in relative numbers versus total bacteria.

\section{Statistical analyses}

All data of the experiment were analyzed using the general linear model procedure of SAS (version 8.0; SAS Inst. Inc., Cary, NC, USA), with pen as the experimental unit. The bacterial counts were transformed $\left(\log _{10}\right)$ before statistical analysis. Statistical differences among treatments were separated by Tukey's HSD test, and considered significant at $\mathrm{p}$ values $<0.05$.

\section{RESULTS}

\section{Growth performance}

During phase I, group $\mathrm{H}$ significantly improved the $\mathrm{G} / \mathrm{F}$ as compared to groups $\mathrm{NC}$ and $\mathrm{PC}(\mathrm{p}<0.05)$, and groups $\mathrm{L}$ and $\mathrm{M}$ had a higher $\mathrm{G} / \mathrm{F}$ than group $\mathrm{NC}(\mathrm{p}<0.05$; Table 3$)$, but no significant difference was found in ADG among 5 groups $(\mathrm{p}>0.05)$. During phase II, groups $\mathrm{PC}$ and $\mathrm{M}$ improved ADG compared with group $\mathrm{NC}(\mathrm{p}<0.05)$, and there was no significant difference in $\mathrm{G} / \mathrm{F}$ among groups $\mathrm{PC}$, $\mathrm{M}$, and $\mathrm{H}$. Throughout the experiment, groups $\mathrm{PC}, \mathrm{M}$, and $\mathrm{H}$ showed improvement in $\mathrm{ADG}$ and $\mathrm{G} / \mathrm{F}$ as compared to group NC ( $\mathrm{p}<0.05)$. However, no significant difference was found in ADFI among the 5 treatments during phases I, II and overall periods $(\mathrm{p}>0.05)$.

\section{Diarrhea incidence}

Dietary treatments had a significant impact on the incidence of diarrhea in piglets (Table 4). During phase I, the probiotics groups had a lower incidence of diarrhea than group NC $(p<0.05)$, and no significant difference was observed in diarrhea incidence between group PC and the other four groups. During phase II and throughout the experiment, the piglets fed diets supplemented with antibiotics or probiotics significantly decreased the incidence of diarrhea compared with the negative control $(\mathrm{p}<0.05)$, and there was no significant difference in the incidence of diarrhea among groups $\mathrm{PC}, \mathrm{M}$, and $\mathrm{H}$.

Table 4. Diarrhea incidence ${ }^{1}$ of weaned piglets fed diet supplemented with antibiotics or B. subtilis

\begin{tabular}{lccccccc}
\hline Item & NC & PC & $\mathrm{L}^{2}$ & $\mathrm{M}^{2}$ & $\mathrm{H}^{2}$ & SEM & $\mathrm{p}$ value \\
\hline Phase I (d 1 to 14,\%) & $4.25^{\mathrm{a}}$ & $3.37^{\mathrm{ab}}$ & $2.27^{\mathrm{b}}$ & $2.78^{\mathrm{b}}$ & $2.22^{\mathrm{b}}$ & 0.24 & 0.016 \\
Phase II (d 15 to 28, \%) & $8.80^{\mathrm{a}}$ & $2.51^{\mathrm{c}}$ & $5.21^{\mathrm{b}}$ & $3.71^{\mathrm{bc}}$ & $3.06^{\mathrm{bc}}$ & 0.57 & $<0.001$ \\
Overall (d 1 to 28, \%) & $6.53^{\mathrm{a}}$ & $2.94^{\mathrm{b}}$ & $3.74^{\mathrm{b}}$ & $3.24^{\mathrm{b}}$ & $2.64^{\mathrm{b}}$ & 0.36 & $<0.001$ \\
\hline
\end{tabular}

NC, negative control, basal diet; PC, positive control, diet supplemented with antibiotics; SEM, standard error of the mean.

${ }^{1}$ Diarrhea incidence $(\%)=$ the total number of diarrheal piglets over a period divided by the number of piglets and days in that period multiplied by 100 .

${ }^{2} \mathrm{~L}, \mathrm{M}, \mathrm{H}=$ diets supplemented with probiotics $2 \times 10^{9}, 4 \times 10^{9}$, and $20 \times 10^{9} \mathrm{CFU} / \mathrm{kg}$ feed, respectively.

${ }^{a, b, c}$ Mean values in the same row with different superscripts differ significantly $(p<0.05)$. 
Bacterial diversity based on polymerase chain reactiondenaturing gradient gel electrophoresis

Figure 1 shows the DGGE fingerprinting profile of the bacterial communities obtained from the 5 samples and their similarities generated by the unweighted pair-group method with arithmetic means (UPGMA). As displayed in Figure 1a, some differences were observed in predominant bands among the 5 groups. However, Figure $1 \mathrm{~b}$ showed a $75 \%$ similarity in the bacterial community structures between groups $\mathrm{NC}$ and $\mathrm{M}$ as well as groups $\mathrm{PC}$ and $\mathrm{H}$, demonstrating that the supplementation of probiotics to the diet changed the bacterial community.

As shown in Table 5, in terms of overall species richness (as estimated by the number of major bands present in DGGE profiles), the piglets supplemented with a medium and a high dose of probiotics (groups $\mathrm{M}$ and $\mathrm{H}$ ) exhibited a higher number of bands than those of groups NC, PC, and L. As for the Shannon-wiener diversity index $\mathrm{H}^{\prime}$ for the bacterial community in the five groups, group $\mathrm{M}$ (2.93) appeared to have a higher bacterial diversity than the others, while group L showed the lowest bacterial diversity (2.52), which was close to group PC (2.59). For the Simpson's index (1/D), the results of bacterial diversity were similar to $\mathrm{H}^{\prime}$. Additionally, no significant difference was found in the species evenness index, but group L was found to have the highest Berger-Parker index in the five groups. The results showed that a right dose of probiotics improved the bacterial community, but a high or low dose reduced the bacterial diversity.

Predominant bands (total number 25, marked with
Table 5. Bacterial diversity index calculated from the DGGE banding patterns (Figure 1a)

\begin{tabular}{lccccc}
\hline Index & $\mathrm{NC}$ & $\mathrm{PC}$ & $\mathrm{L}^{1}$ & $\mathrm{M}^{1}$ & $\mathrm{H}^{1}$ \\
\hline Species richness (S) & 23 & 19 & 18 & 27 & 24 \\
Shannon's index (H') & 2.8 & 2.59 & 2.52 & 2.93 & 2.82 \\
Species evenness (J) & 0.89 & 0.88 & 0.87 & 0.89 & 0.89 \\
Berger-Parker index (d) & 0.152 & 0.145 & 0.173 & 0.119 & 0.131 \\
Simpson's index (1/D) & 13.18 & 11.21 & 9.98 & 15.47 & 13.40
\end{tabular}

$\mathrm{NC}$, negative control, basal diet; PC, positive control, diet supplemented with antibiotics); SEM, standard error of the mean

${ }^{1} \mathrm{~L}, \mathrm{M}, \mathrm{H}=$ diets supplemented with probiotics $2 \times 10^{9}, 4 \times 10^{9}$ and $20 \times 10^{9}$ CFU/kg feed, respectively.

${ }^{2} 1 / \mathrm{D}$, reciprocal of Simpson's diversity index.

numbers in Figure 1a) were excised and re-amplified to identify species in the samples (Table 6). The sequence similarity of each band was $\geq 97 \%$ (except $94 \%$ for band 23 ) as compared with that available in GenBank database. As shown in Figure 1a, major differences are present in bands $3,7,12,15,22,23,24,25$, and 30 . When compared to the negative control NC, the antibiotics promoted the growth of bacteria related to uncultured bacteria (15), Lactobacillus amylovorus (23), uncultured Lachnospiraceae bacterium (24) and Lactobacillus kitasatoni (30), and inhibited the bacteria related to Eubacterium eligens (3), uncultured bacterium (7) and Ruminococcus sp. (22). The probiotics groups $\mathrm{M}$ and $\mathrm{H}$ promoted the bacteria related to Eubacterium coprostanoligenes (12), L. amylovorus (23), uncultured Lachnospiraceae bacterium (24) and $L$. kitasatoni (30). In lane $\mathrm{H}$, a new band 25 related to Faecalibacterium prausnitzii was found as compared to the

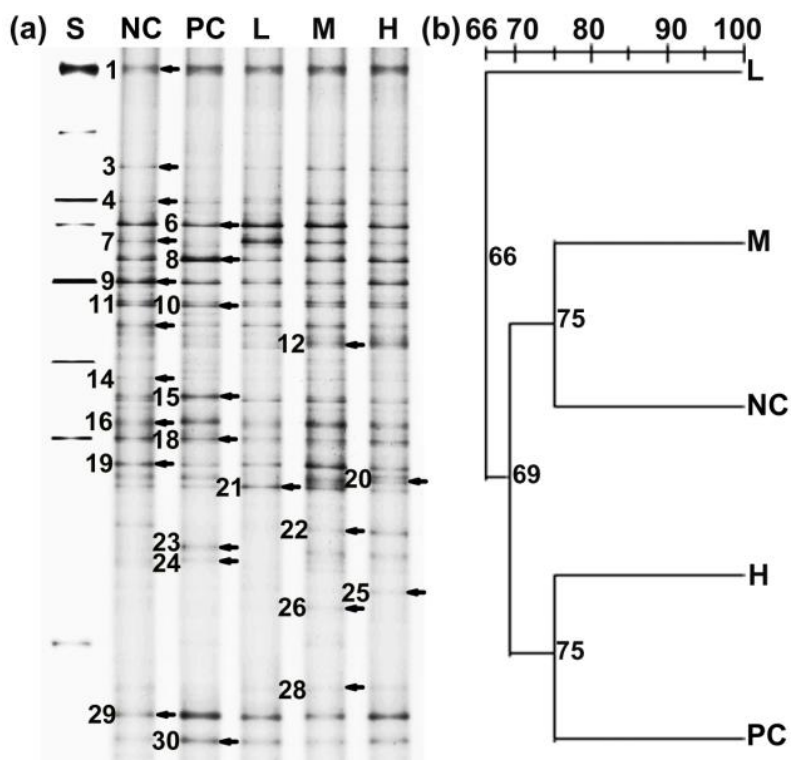

Figure 1. Bacterial community of weaned piglets fed diet supplemented with antibiotics or B. subtilis. (a) DGGE profiles of the V6 to V8 regions of the $16 \mathrm{~S}$ rDNA gene fragments from the samples. The denaturant gradient range is $42 \%$ to $58 \%$ and the major difference bands are numbered. Lane $\mathrm{S}$ (Standard ladder, which indicates PCR products generated from different bacterial 16S rDNA genes with primers 968F-GC and 1401R); NC (negative control, basal diet); PC (positive control, diet supplemented with antibiotics); L, M, H (diets supplemented with probiotics $2 \times 10^{9}$, $4 \times 10^{9}$, and $20 \times 10^{9}$ CFU/kg feed, respectively); (b) Unweighted pair-group method with arithmetic means (UPGMA) analysis of Dice similarity indices from DGGE profiles. DGGE, denaturing gradient gel electrophoresis; PCR, polymerase chain reaction. 
Table 6. Identification of band fragments in DGGE gels (Figure 1a)

\begin{tabular}{|c|c|c|}
\hline Band no. $^{1}$ & Closest relative and NCBI accession number & Identity $(\%)^{2}$ \\
\hline 1 & Uncultured bacterium (JQ187036.1) & 99 \\
\hline 3 & Eubacterium eligens ATCC 27750 (СР001104.1) & 97 \\
\hline 4 & Uncultured bacterium (NR_025207.1) & 97 \\
\hline 6 & Robinsoniella peoriensis (AF445283.2) & 96 \\
\hline 7 & Uncultured bacterium (HQ716245.1) & 100 \\
\hline 8 & Ruminococcus sp. (FJ611794.2) & 100 \\
\hline 9 & Clostridium irregulare (JX898025.1) & 97 \\
\hline 10 & Uncultured bacterium (JQ820130.1) & 100 \\
\hline 11 & Clostridiaceae bacterium (EU728782.1) & 98 \\
\hline 12 & Eubacterium coprostanoligenes (HM037995.1) & 99 \\
\hline 14 & Swine manure bacterium (AY167964.1) & 99 \\
\hline 15 & Uncultured bacterium (FP077070.1) & 100 \\
\hline 16 & Uncultured Clostridium sp. (GQ868439.1) & 99 \\
\hline 18 & Uncultured Firmicutes bacterium (JN568109.1) & 100 \\
\hline 19 & Lachnospiraceae bacterium (EU728751.1) & 99 \\
\hline 20 & Ruminococcus obeum (AY169411.1) & 100 \\
\hline 21 & Uncultured bacterium (EU472437.1) & 97 \\
\hline 22 & Ruminococcus sp. (EU728789.1) & 97 \\
\hline 23 & Lactobacillus amylovorus (CP002609.1) & 94 \\
\hline 24 & Uncultured Lachnospiraceae bacterium (JX230492.1) & 100 \\
\hline 25 & Faecalibacterium prausnitzii (AY169430.1) & 99 \\
\hline 26 & Uncultured bacterium clone (FJ880520.1) & 97 \\
\hline 28 & Ruminococcus sp. (EU728790.1) & 99 \\
\hline 29 & Lactobacillus reuteri $(\mathrm{CP} 006603.1)$ & 99 \\
\hline 30 & Lactobacillus kitasatonis DSM 16761T (FR683090.1) & 98 \\
\hline
\end{tabular}

DGGE, denaturing gradient gel electrophoresis.

${ }^{1}$ Bands are numbered according to Figure 1a. ${ }^{2}$ Identity represents the sequence identity (\%) compared with that in the GenBank database.

other 4 groups.

\section{Quantitative real-time polymerase chain reaction analysis}

The quantification of $16 \mathrm{~S}$ rDNA gene copy numbers from faecal samples revealed that densities of Lactobacillus were significantly higher in groups $\mathrm{H}$ and $\mathrm{PC}$ than in the negative control $(p<0.05)$, and the relative number of Lactobacillus increased with an increasing dose of probiotics, indicating that the antibiotics and probiotics improved the growth of Lactobacillus (Table 7). In addition, the supplementation of antibiotics and probiotics significantly decreased the relative number of $E$. coli $(p<0.05)$, but no significant difference was observed in the relative densities of total bacteria $(p>0.05)$.

\section{DISCUSSION}

Several strains of $B$. subtilis can be used as feed additives, and no safety concerns are identified when used in direct-fed microbial products (Sen et al., 2012; Cui et al., 2013; Lee et al., 2014). We hypothesized that B. subtilis would help the balance of microflora by stimulating the beneficial bacteria, thereby improving gut health, reducing diarrhea incidence indirectly, and enhancing the growth performance. The PCR-DGGE has been successfully used to study the taxonomy of bacterial communities in the pigs (Petersson et al., 2009; Han et al., 2011). The microbiota of

Table 7. Real-time PCR analysis of total bacterial counts and relative contributions of 5 bacterial groups ${ }^{1}$

\begin{tabular}{lccccccc}
\hline Item & $\mathrm{NC}$ & $\mathrm{PC}$ & $\mathrm{L}^{2}$ & $\mathrm{M}^{2}$ & $\mathrm{H}^{3}$ & SEM & $\mathrm{p}$ value \\
\hline Total bacteria $\left(\log ^{10}\right.$ copies $\left./ \mu \mathrm{L}\right)$ & 8.11 & 8.33 & 8.27 & 8.17 & 8.21 & 0.04 & 0.372 \\
Lactobacillus $(\%)$ & $15.40^{\mathrm{b}}$ & $28.85^{\mathrm{a}}$ & $15.75^{\mathrm{b}}$ & $17.70^{\mathrm{ab}}$ & $29.60^{\mathrm{a}}$ & 1.81 & 0.004 \\
Escherichia coli $\left(10^{-2}, \%\right)$ & $5.25^{\mathrm{a}}$ & $0.87^{\mathrm{b}}$ & $2.26^{\mathrm{b}}$ & $1.71^{\mathrm{b}}$ & $2.27^{\mathrm{b}}$ & 0.36 & $<0.001$
\end{tabular}

PCR, polymerase chain reaction; NC, negative control, basal diet; PC, positive control, diet supplemented with antibiotics; SEM, standard error of the
mean.

${ }^{1}$ Faecal samples were taken from 5 weaned piglets per treatment.

${ }^{2} \mathrm{~L}, \mathrm{M}, \mathrm{H}=$ diets supplemented with probiotics $2 \times 10^{9}, 4 \times 10^{9}$, and $20 \times 10^{9} \mathrm{CFU} / \mathrm{kg}$ feed, respectively.

${ }^{a, b}$ Mean values in the same row with different superscripts differ significantly $(p<0.05)$. 
animals usually show considerable variations between individuals (Petersson et al., 2009), and whether these variations are due to different treatments or to naturally occurring deviations is not always known (Gong et al., 2008). In order to reduce individual differences in microbiota, we mixed the 5 samples from the same group together for DGGE analysis. Additionally, qPCR was used to investigate the precise and profound changes in the abundances of Lactobacillus and E. coli.

Weaning is a stressful period in the life cycle of pigs, which is associated with changes in diet, gut environment and gut morphology, and thus may result in low growth rate, high diarrhea incidence and imbalanced intestinal microecology (Giang et al., 2012). These problems can be reduced by supplementing the diet with probiotics. Previous studies reported that the addition of $B$. subtilis var. natto improved the growth and feed intake of geese (Chen et al., 2013), and the diets supplemented with $10^{8} \mathrm{CFU} / \mathrm{kg}$ feed of B. subtilis improved the ADG of broilers (Zhang et al., 2012). Other researchers also reported that the supplementation of $B$. subtilis to diet improved the growth performance of pigs (Alexopoulos et al., 2004; Wang et al., 2011; Lee et al., 2014). However, several studies failed to find its positive effects on the growth performance of animals (Willis and Reid, 2008; Lee et al., 2010).

The growth performance may be linked to diarrhea incidence, and thus the diarrhea incidence of piglets was recorded daily in this study. The data indicated that diets supplemented with probiotics significantly reduced the incidence of diarrhea of piglets, which is consistent with several previous studies. It is reported that supplementation of probiotics to pig diets decreased the diarrhea score (Alexopoulos et al., 2004), and induced a 59\% decrease in diarrhea incidence (Taras et al., 2005). Also, a previous study suggested that $B$. subtilis reduced Citrobacter rodentium-induced diarrhea of mice (Jones and Knight, 2012). It can be deduced from these results that B. subtilis can effectively prevent diarrhea in weaned piglets.

Lactobacillus is considered as a beneficial bacterium for the balance of intestinal microbiota, due to its healthpromoting effects such as prevention of diarrhea and intestinal infections. A previous study on intestinal microbiota of weaned piglets has shown that after weaning, E. coli concentrations increased while the number of Lactobacillus decreased (Konstantinov et al., 2006). In this study, the result of qPCR analysis showed that the relative number of Lactobacillus increased in piglets treated with antibiotics and probiotics, and DGGE profiles also showed the number of bacteria related to $L$. amylovorus and $L$. kitasatoni increased. Neomycin sulfate usually inhibits the growth of gram-negative bacteria and some of the grampositive bacteria, such as Escherichia, Klebsiella and
Corynebacterium. However, the genus Lactobacillus belongs to the gram-positive bacteria which are not the main bacteria inhibited by Neomycin sulfate. It was reported that pigs supplemented with antibiotics had a higher Lactobacillus in the ileum than the control (Li et al., 2008). Previous studies have also found that the compound probiotics containing $B$. subtilis increased lactic acid bacteria (Giang et al., 2012), and the number of Lactobacillus was significantly greater in the probiotics groups than in the control (Han et al., 2013). Additionally, it has been reported that an increment of Lactobacillus results in a relative decrease in other bacteria such as Clostridia and Coliforms (Vanhoutte et al., 2006).

As we know, E. coli is one of the major sources of intestinal pathogens, and a few strains can induce serious illness, including diarrhea. In the post-weaning period, supplementation of probiotics to pig diets is essential for the prophylaxis of diarrhea, which is usually induced by enterotoxigenic $E$. coli strains. A previous study reported that oral administration of B. subtilis DB9011 in weaned piglets inhibited the growth of Shiga toxin 2e-producing $E$. coli in the ileum (Tsukahara et al., 2013). The probiotics were also found to reduce $E$. coli counts in the intestine of piglets (Giang et al., 2012). Therefore, an increase of Lactobacillus and a decrease of E. coli may, to a degree, result in a lower diarrhea incidence in antibiotics and probiotics groups.

The bacterial diversity could represent a benefit for the weaned animals because of the possible link between the diversity of ecosystems and their ability to respond to perturbations (McCann, 2000). The diversity of the microbiota is usually represented by the number of identifiable DGGE bands. The results showed that group M had the highest number of bands and the highest bacterial diversity in the five groups. Taras et al. (2007) reported that the bacterial community of pigs could be modified by supplementation of E. faecium, and Pieper et al. (2009) found that piglets treated with Lactobacillus plantarum increased the Simpson's diversity index. Furthermore, $B$. subtilis was observed to have beneficial effects on caecal microflora in broiler chicks (Sen et al., 2011).

Most of the species identified from the DGGE profiles are uncultured bacteria, and largely belong to Firmicutes. It is found that most of the intestinal microbes cannot be cultured, and Firmicutes constitute a large portion of the faecal community (Eckburg et al., 2005). In this study, the major difference bands related to culturable bacteria are $E$. eligens, E. coprostanoligenes, Ruminococcus sp., $L$. amylovorus, L. kitasatonis and F. prausnitzii. Among them, E. eligens is known to belong to Clostridium Cluster XIVa, which is one of the most common gut Firmicute clades, and consists of many species producing butyrate, acetate and 
lactate (Pryde et al., 2002). Eubacterium coprostanoligenes, a small gram-positive and cholesterol-reducing anaerobe, promotes the conversion of cholesterol to coprostanol (Madden et al., 1999). Several strains of Ruminococcus were identified to be present as active bacteria and important members of the bacterial community in the human gastrointestinal tract, and beneficial for the digestion of crude fibre (Zoetendal et al., 1998). Interestingly, a band related to $F$. prausnitzii, which was detected in group $\mathrm{H}$. The $F$. prausnitzii, is one of the most abundant commensal bacteria in the healthy human large intestine (Lopez-Siles et al., 2012), and serves as an anti-inflammatory bacterium that can be used for Crohn's disease treatment (Sokol et al., 2008). Whether this major difference bacterium affects the health of piglets is a very complicated issue and remains to be elucidated.

In conclusion, this study has found that $B$. subtilis $\mathrm{KN}$ 42 effectively improved the growth performance of piglets and reduced the incidence of diarrhea in the weaned piglets. Furthermore, B. subtilis $\mathrm{KN}-42$ also improved the bacterial diversity of the intestinal environment, increased the relative number of Lactobacillus and reduced the relative number of $E$. coli in the faeces of weaned piglets. These results suggest that $B$. subtilis $\mathrm{KN}-42$ can serve as an alternative to antibiotics in diets for weaned piglets.

\section{ACKNOWLEDGMENTS}

The authors kindly thank Hainan Agri-Farming Animal Husbandry Group CO., LTD for providing animals, farm and assistance in caring piglets and collection of samples. This work was financially supported by grants 31100050 and 31100096 from the NSFC, and by grant 2011QC025 of the Fundamental Research Funds for the Central Universities.

\section{REFERENCES}

Alexopoulos, C., I. E. Georgoulakis, A. Tzivara, S. K. Kritas, A. Siochu, and S. C. Kyriakis. 2004. Field evaluation of the efficacy of a probiotic containing Bacillus licheniformis and Bacillus subtilis spores, on the health status and performance of sows and their litters. J. Anim. Physiol. Anim. Nutr. 88: 381-392.

Aliakbarpour, H. R., M. Chamani, G. Rahimi, A. A. Sadeghi, and D. Qujeq. 2012. The Bacillus subtilis and lactic acid bacteria probiotics influences intestinal mucin gene expression, histomorphology and growth performance in broilers. Asian Australas. J. Anim. Sci. 25:1285-1293.

ben Omar, N. and F. Ampe. 2000. Microbial community dynamics during production of the Mexican fermented maize dough pozol. Appl. Environ. Microbiol. 66:3664-3673.

Chen, W., X. Z. Zhu, J. P. Wang, Z. X. Wang, and Y. Q. Huang. 2013. Effects of Bacillus subtilis var. natto and Saccharomyces cerevisiae fermented liquid feed on growth performance, relative organ weight, intestinal microflora, and organ antioxidant status in Landes geese. J. Anim. Sci. 91:978-985.

Cui, C., C. J. Shen, G. Jia, and K. N. Wang. 2013. Effect of dietary Bacillus subtilis on proportion of Bacteroidetes and Firmicutes in swine intestine and lipid metabolism. Genet. Mol. Res. 12: 1766-1776.

Eckburg, P. B., E. M. Bik, C. N. Bernstein, E. Purdom, L. Dethlefsen, M. Sargent, S. R. Gill, K. E. Nelson, and D. A. Relman. 2005. Diversity of the human intestinal microbial flora. Science 308:1635-1638.

Fu, C. J., J. N. Carter, Y. Li, J. H. Porter, and M. S. Kerley. 2006. Comparison of agar plate and real-time PCR on enumeration of Lactobacillus, Clostridium perfringens and total anaerobic bacteria in dog faeces. Lett. Appl. Microbiol. 42:490-494.

Giang, H. H., T. Q. Viet, B. Ogle, and J. E. Lindberg. 2012. Growth performance, digestibility, gut environment and health status in weaned piglets fed a diet supplemented with a complex of lactic acid bacteria alone or in combination with Bacillus subtilis and Saccharomyces boulardii. Livest. Sci. 143:132-141.

Gong, J., H. Yu, T. Liu, M. Li, W. Si, C. F. M. De lange, and C. Dewey. 2008. Characterization of ileal bacterial microbiota in newly-weaned pigs in response to feeding lincomycin, organic acids or herbal extract. Livest. Sci. 116:318-322.

Han, K. S., P. Balan, F. Molist Gasa, and M. Boland. 2011. Green kiwifruit modulates the colonic microbiota in growing pigs. Lett. Appl. Microbiol. 52:379-385.

Han, W., X. L. Zhang, D. W. Wang, L. Y. Li, G. L. Liu, A. K. Li, and Y. X. Zhao. 2013. Effects of microencapsulated Enterococcus fecalis CG1.0007 on growth performance, antioxidation activity, and intestinal microbiota in broiler chickens. J. Anim. Sci. 91:4374-4382.

Hong, H. A., L. H. Duc, and S. M. Cutting. 2005. The use of bacterial spore formers as probiotics. FEMS Microbiol. Rev. 29:813-835.

Hu, Y., X. Yang, J. Qin, N. Lu, G. Cheng, N. Wu, Y. Pan, J. Li, L. Zhu, and X. Wang et. al. 2013. Metagenome-wide analysis of antibiotic resistance genes in a large cohort of human gut microbiota. Natr. Commun. 4. Article number 2151.

Jones, S. E. and K. L. Knight. 2012. Bacillus subtilis-mediated protection from Citrobacter rodentium-associated enteric disease requires esph and functional flagella. Infect. Immun. 80:710-719.

Kim, Y. I., Y. H. Lee, K. H. Kim, Y. K. Oh, Y. H. Moon, and W. S. Kwak. 2012. Effects of supplementing microbially-fermented spent mushroom substrates on growth performance and carcass characteristics of Hanwoo steers (a field study). Asian Australas. J. Anim. Sci. 25:1575-1581.

Konstantinov, S. R., A. A. Awati, B. A. Williams, B. G. Miller, P. Jones, C. R. Stokes, A. D. L. Akkermans, H. Smidt, and W. M. De Vos. 2006. Post-natal development of the porcine microbiota composition and activities. Environ. Microbiol. 8: 1191-1199.

Lee, D. H., Y. G. Zo, and S. J. Kim. 1996. Nonradioactive method to study genetic profiles of natural bacterial communities by PCR-single-strand-conformation polymorphism. Appl. Environ. Microbiol. 62:3112-3120.

Lee, K. W., S. H. Lee, H. S. Lillehoj, G. X. Li, S. I. Jang, U. S. 
Babu, M. S. Park, D. K. Kim, E. P. Lillehoj, A. P. Neumann, T. G. Rehberger, and G. R. Siragusa. 2010. Effects of direct-fed microbials on growth performance, gut morphometry, and immune characteristics in broiler chickens. Poult. Sci. 89:203216

Lee, S. H., S. L. Ingale, J. S. Kim, K. H. Kim, A. Lokhande, E. K. Kim, I. K. Kwon, Y. H. Kim, and B. J. Chae. 2014. Effects of dietary supplementation with Bacillus subtilis LS 1-2 fermentation biomass on growth performance, nutrient digestibility, cecal microbiota and intestinal morphology of weanling pig. Anim. Feed Sci. Technol. 188:102-110.

Li, M., J. Gong, M. Cottrill, H. Yu, C. de Lange, J. Burton, and E. Topp. 2003. Evaluation of QIAamp ${ }^{\circledR}$ DNA Stool Mini Kit for ecological studies of gut microbiota. J. Microbiol. Methods 54: 13-20.

Li, Z., G. Yi, J. Yin, P. Sun, D. Li, and C. Knight. 2008. Effects of organic acids on growth performance, gastrointestinal $\mathrm{pH}$, intestinal microbial populations and immune responses of weaned pigs. Asian Australas. J. Anim. Sci. 21:252-261.

Lopez-Siles, M., T. M. Khan, S. H. Duncan, H. J. M. Harmsen, L. J. Garcia-Gil, and H. J. Flint. 2012. Cultured representatives of two major phylogroups of human colonic Faecalibacterium prausnitzii can utilize pectin, uronic acids, and host-derived substrates for growth. Appl. Environ. Microbiol. 78:420-428.

Madden, U. A., G. D. Osweiler, L. Knipe, G. W. Beran, and D. C. Beitz. 1999. Effects of Eubacterium coprostanoligenes and Lactobacillus on $\mathrm{pH}$, lipid content, and cholesterol of fermented pork and mutton sausage-type mixes. J. Food Sci. 64:903-908

McCann, K. S. 2000. The diversity-stability debate. Nature 405: 228-233.

Nakano, M. M. and P. Zuber. 1998. Anaerobic growth of a "strict aerobe" (Bacillus subtilis). Annu. Rev. Microbiol. 52:165-190.

NRC. 1998. Nutrient Requirements of Swine. 10th ed. National Academies Press, Washington, DC, USA.

Petersson, A., K. J. Domig, P. Nagel, W. Zollitsch, W. Hagmüller, and W. Kneifel. 2009. Denaturing gradient gel electrophoresis (DGGE)-based monitoring of intestinal Lactobacilli and Bifidobacteria of pigs during a feeding trial. Arch. Anim. Nutr. 63:112-126.

Pieper, R., P. Janczyk, V. Urubschurov, U. Korn, B. Pieper, and W. B. Souffrant. 2009. Effect of a single oral administration of Lactobacillus plantarum DSMZ 8862/8866 before and at the time point of weaning on intestinal microbial communities in piglets. Int. J. Food Microbiol. 130:227-232.

Pryde, S. E., S. H. Duncan, G. L. Hold, C. S. Stewart, and H. J. Flint. 2002. The microbiology of butyrate formation in the human colon. FEMS Microbiol. Lett. 217:133-139.

Ricca, D. M., C. J. Ziemer, and B. J. Kerr. 2010. Changes in bacterial communities from swine feces during continuous culture with starch. Anaerobe 16:516-521.

Sen, S., S. L. Ingale, Y. W. Kim, J. S. Kim, K. H. Kim, J. D. Lohakare, E. K. Kim, H. S. Kim, M. H. Ryu, I. K. Kwon, and B. J. Chae. 2012. Effect of supplementation of Bacillus subtilis LS 1-2 to broiler diets on growth performance, nutrient retention, caecal microbiology and small intestinal morphology. Res. Vet. Sci. 93: 264-268.

Sen, S., S. L. Ingale, J. S. Kim, K. H. Kim, Y. W. Kim, C. Khong, J. D. Lohakare, E. K. Kim, H. S. Kim, I. K. Kwon, and B. J.
Chae. 2011. Effect of supplementation of Bacillus subtilis LS 1-2 grown on citrus-juice waste and corn-soybean meal substrate on growth performance, nutrient retention, caecal microbiology and small intestinal morphology of broilers. Asian Australas. J. Anim. Sci. 24:1120-1127.

Sindhu, S. C. and N. Khetarpaul. 2003. Effect of feeding probiotic fermented indigenous food mixture on serum cholesterol levels in mice. Nutr. Res. 23:1071-1080.

Smillie, C. S., M. B. Smith, J. Friedman, O. X. Cordero, L. A. David, and E. J. Alm. 2011. Ecology drives a global network of gene exchange connecting the human microbiome. Nature 480:241-244.

Sokol, H., B. Pigneur, L. Watterlot, O. Lakhdari, L. G. BermúdezHumarán, J.-J. Gratadoux, S. Blugeon, C. Bridonneau, J.-P. Furet, and G. Corthier et al. 2008. Faecalibacterium prausnitzii is an anti-inflammatory commensal bacterium identified by gut microbiota analysis of Crohn disease patients. Proc. Natl. Acad. Sci. USA. 105:16731-16736.

Srinivasan, S., A. Aslan, I. Xagoraraki, E. Alocilja, and J. B. Rose. 2011. Escherichia coli, Enterococci, and Bacteroides thetaiotaomicron qPCR signals through wastewater and septage treatment. Water Res. 45: 2561-2572.

Taras, D., W. Vahjen, M. Macha, and O. Simon. 2005. Response of performance characteristics and fecal consistency to longlasting dietary supplementation with the probiotic strain Bacillus cereus var. toyoi to sows and piglets. Arch. Anim. Nutr. 59:405-417.

Taras, D., W. Vahjen, and O. Simon. 2007. Probiotics in pigs modulation of their intestinal distribution and of their impact on health and performance. Livest. Sci. 108:229-231.

Tsukahara, T., T. Tsuruta, N. Nakanishi, C. Hikita, M. Mochizuki, and K. Nakayama. 2013. The preventive effect of Bacillus subtilus strain DB9011 against experimental infection with enterotoxcemic Escherichia coli in weaning piglets. Anim. Sci. J. 84:316-321.

van Orsouw, N., D. Li, and J. Vijg. 1997. Denaturing gradient gel electrophoresis (DGGE) increases resolution and informativity of Alu-directed inter-repeat PCR. Mol. Cell. Probes 11:95-101.

Vanhoutte, T., V. De Preter, E. De Brandt, K. Verbeke, J. Swings, and G. Huys. 2006. Molecular monitoring of the fecal microbiota of healthy human subjects during administration of lactulose and Saccharomyces boulardii. Appl. Environ. Microbiol. 72: 5990-5997.

Vondruskova, H., R. Slamova, M. Trckova, Z. Zraly, and I. Pavlik. 2010. Alternatives to antibiotic growth promoters in prevention of diarrhoea in weaned piglets: A review. Vet. Med-Czech. 55: 199-224.

Walter, J., G. W. Tannock, A. Tilsala-Timisjarvi, S. Rodtong, D. M. Loach, K. Munro, and T. Alatossava. 2000. Detection and identification of gastrointestinal Lactobacillus species by using denaturing gradient gel electrophoresis and species-specific PCR primers. Appl. Environ. Microbiol. 66:297-303.

Wang, S. P., L. Yang, X. S. Tang, L. C. Cai, G. Liu, X. F. Kong, F. Blachier, and Y. L. Yin. 2011. Dietary supplementation with high-dose Bacillus subtilis or Lactobacillus reuteri modulates cellular and humoral immunities and improves performance in weaned piglets. J. Food Agric. Environ. 9:181-187.

Willis, W. and L. Reid. 2008. Investigating the effects of dietary probiotic feeding regimens on broiler chicken production and 
Campylobacter jejuni presence. Poult. Sci. 87:606-611.

Zhang, Z. F., T. X. Zhou, X. Ao, and I. H. Kim. 2012. Effects of $\beta$ glucan and Bacillus subtilis on growth performance, blood profiles, relative organ weight and meat quality in broilers fed maize-soybean meal based diets. Livest. Sci. 150:419-424.
Zoetendal, E. G., A. D. L. Akkermans, and W. M. De Vos. 1998. Temperature gradient gel electrophoresis analysis of $16 \mathrm{~S}$ rRNA from human fecal samples reveals stable and host-specific communities of active bacteria. Appl. Environ. Microbiol. 64: 3854-3859. 